\title{
Farmer perceptions of reasons for perennial pasture persistence and the relationship of these with management practice, species composition, and soil fertility
}

\author{
M.J. DALY ${ }^{1}$, T. FRASER ${ }^{1}$, A. PERKINS ${ }^{2}$ and C.M. MOFFAT ${ }^{3}$ \\ ${ }^{1}$ AgResearch Lincoln, PO Box 60, Lincoln \\ ${ }^{2}$ Environment Waikato, PO Box 3010, Hamilton East \\ ${ }^{3}$ AgResearch Poukawa, PO Box 8144, Havelock North
}

\begin{abstract}
During 1997/98, a postal survey of 100 sheep and beef pastoral farms asked the farmers a range of questions based around pasture performance and their perceptions on persistence, and asked them to identify a persistent paddock on their farm. The farmers were then interviewed on the management of the chosen persistent paddock and the paddock was assessed for composition and fertility. The farmers ranked pasture species persistence fourth, behind pasture quality, animal health, and soil fertility in terms of importance to the whole farm system. The difference was significant between pasture quality and pasture persistence. The persistent pastures, as identified by the farmers, had high levels of desirable species and low levels of weeds and low-fertility volunteer species. The survey showed some pastures can persist and maintain high levels of desirable species for periods over 21 years. Fertility is a key factor in pasture persistence followed by drainage and grazing management.
\end{abstract}

Keywords: farm management, farm survey, farmers' perceptions, interview, pasture persistence, species composition, soil fertility

\section{Introduction}

Regrassing is a significant cost to pastoral farmers when pastures fail to persist and paddocks have to be resown or they are left as a low producing, low quality pasture. Understanding the factors that lead to better persistence of pasture species is therefore important for improving the economic sustainability of pastoral farms.

Farmers are an important source of knowledge for determining both the key factors affecting pasture persistence and for providing indications of the importance of various farm management practices. To substantiate anecdotal evidence it is important to collect quantitative data by measuring actual farm pastures. This combination then provides us with the data to develop accurate and relevant information technology to feed back to the farmers.
The research reported in this paper is the first stage of a larger three-stage programme, aimed at identifying the farm practices and environmental conditions that can extend the persistence of new pastures. This first stage identified currently persistent paddocks on 100 selected farms and the farmers who managed these pastures were interviewed to determine the on-farm practices they believed affected the persistence and stability of these perennial pasture mixtures. The second stage, which has started, is evaluating actual changes in the persistence of sown pasture species during their first 6 years after establishment, and monitoring management inputs. This long-term monitoring of paddocks, together with the associated data collection, is planned to identify how factors influencing pasture persistence interact over time and affect botanical composition. Based on the knowledge generated from the first two stages of the project, recommendations will be made for improving pasture persistence for different climatic zones, soil types and pasture types. This paper presents results from the first stage or 'Benchmark' part of the programme.

\section{Background}

There is a wealth of practical knowledge and experience about pasture persistence that can be gained only by studying how farmers evaluate pasture, the factors that farmers believe to affect persistence, and how farmers make pasture management decisions.

The focus of this research was the persistence of sown pasture species. However, farmers manage pasture on a paddock basis as part of a whole farm grazing system, rather than for the purpose of maintaining species. Hence it was decided that the biological study of pasture species needed to relate to the whole farm system. For these reasons the 'Benchmark' research was designed to address the following research questions:

- What observations have farmers made about the pasture?

- How have farmers managed pastures that they believe to be persistent?

- What are the factors that farmers believe contribute to pasture persistence? 
- How do farmer's perceptions relate to quantitative assessments of pasture species composition and fertility?

\section{Methods}

During 1997/98, a survey of 100 sheep and beef pastoral farms was carried out. The survey included farms in Southland, Otago and Canterbury in the South Island, and Hawke's Bay, Manawatu/Wanganui and Waikato/ South Auckland/Bay of Plenty in the North Island. The paddocks included in the study were a minimum of 5 years of age, with a species mix based around either, ryegrass, cocksfoot, tall fescue, chicory, or combinations of these in the original sowing. Legumes were generally included at sowing as a secondary component in all the pastures.

Information about the value of pasture persistence to farmers in relation to their overall farming operation, and also the parameters that farmers use when assessing pasture management, and their beliefs and perceptions, were studied using qualitative social research methods. The biological factors of soil fertility, and species presence were evaluated using objective measurements. The survey had three distinctive parts:

1. In the first part of the study participants completed a written postal questionnaire. The semi-structured design allowed for open responses to questions about the best, worst and most persistent pastures on the farm, and the roles of each of these pastures within their farming operation. The farmers were invited to respond with key phrases rather than full sentences. The data is presented using the farmers' own phrases. Quantitative data about the farm and pasture management in terms of stock policy, soil fertility management, pasture sowing and species selection, were also collected. At the end of the questionnaire, the farmers nominated what they believed to be the most persistent pasture on their farms, and these became the survey paddocks for the study.

2. Responses to the postal survey identified key parameters which participants thought to be related to persistence. This information was used to design the second part of the study - a comprehensive interview questionnaire. The interview prompted for more detail on how each manager perceived the influence of soil fertility, drainage, soil moisture, and grazing management. The farmers were also asked to rank 11 different factors (including pasture persistence) in terms of their importance to the overall farming operation.

3. The third part of the survey was a quantitative pasture species and soil fertility assessment of the survey paddocks. These measurements were made between July and October 1998. Species were assessed by taking 100 turf cores (Mitchell \& Glenday 1958) from each survey paddock. The cores were $50 \mathrm{~mm}$ in diameter and $50 \mathrm{~mm}$ deep. Each core was pulled apart in the laboratory to determine the species present. Bare ground was recorded when no plant species were present. Soil fertility was assessed by taking 20 standard soil fertility cores (depth $75 \mathrm{~mm}$ ), collected from each survey paddock and bulked for analysis of Olsen $\mathrm{P}$, sulphate $\mathrm{S}$, organic $\mathrm{S}, \mathrm{K}, \mathrm{Ca}$, $\mathrm{Na}, \mathrm{Mg}$ and $\mathrm{pH}$ (AgResearch 1997).

\section{Statistical analysis}

The ratings assigned by the farmers of the relative importance of individual farming factors were statistically analysed (collectively) using analysis of variance (ANOVA), treating the 11 questions as 'treatments' and the 102 farms as 'blocks', as in a randomised block analysis. This ANOVA was followed by an unrestricted LSD test (Saville 1990).

The percentage occurrences of individual species in the turf cores, and the soil fertility variables were each analysed (separately) using an unequally replicated single factor ANOVA, with 'treatments, being three pasture categories. For each variable, LSD letters were then assigned on the basis of the significance of the differences between pasture categories.

\section{Results}

This section of the paper reports the survey results in the order of how farmers evaluated pasture within their overall farm management, followed by their assessment and management of the survey paddock, and concludes with comparison of these factors in relation to quantitative assessment of that paddock.

\section{How farmers recognise and define differences between their paddocks}

This exercise allowed the farmers the opportunity to think about differences in the performance of their pastures from a whole farm perspective, and to categorise those differences. Most importantly, it allowed them to identify their most persistent paddock which then became the survey paddock in this study (Table 1).

The farmers most commonly described their best and worst paddocks in terms of high verses low animal performance, high verses low pasture production, and associated species and age as factors linked to these descriptions (Table 1). The persistent pasture also had species and age in the top four categories, which are either inherent (species) or consequential (age) factors, 
independent of management. Most importantly, they have linked the causative factors of grazing management and fertility management as the features of their persistent pasture. This indicated that they perceived that they had a reasonable amount of control over influences on pasture persistence.

Animal performance was not linked to persistence. This does not mean that animal performance (good or bad) was not a consequence of a persistent pasture, just that it was not considered to have influenced or caused the end product, i.e., the persistent pasture.

\section{What important factors and significant events do farmers perceive may have influenced this paddock to be persistent?}

The farmers were asked this question in a slightly different context to the question in Table 1 , and the responses (highest 6) showed more emphasis on fertility management and grazing management than species (Table 2).

\section{How farmers rank the importance of pasture persistence alongside other management factors on their farms}

During the personal interview, farmers were asked to rate the importance of 11 factors in relation to their overall farming operation. The ratings were combined across farmers to indicate the relative importance of pasture species persistence compared with other factors (Table 3).

Pasture species persistence was ranked fourth, behind pasture quality, animal health, and soil fertility in terms of importance to the whole farm system. These differences were significant between pasture quality and pasture persistence $(\mathrm{P}<0.05)$. This indicates that farmers in our survey see pasture quality and animal health as the most important factors influencing their farming operation, and consider fertility and persistence to be a similar but lower rank than the former two factors, which are centred around animal performance. While this links to Table 1, in which animal performance was a feature of their best paddock, a clear association cannot be drawn between pasture persistence and animal performance.

Farmers perceptions of how long a perennial pasture should last, and the actual rate of pasture renewal on farms

Around $30 \%$ of farmers expect a perennial pasture to last 21 years or more (Table 4). This equates with the pastures nominated and sampled for the survey that were classified as 21 years and older $(32 \%)$. There were $50 \%$ of survey paddocks in the 5-10 years category and a significant number of these could be expected to
Table 1 Farmer defined characteristics of "Best", "Worst" and "Persistent" paddocks on their farm (highest four catergories - 102 sample size)

\begin{tabular}{lc}
\hline Question asked & \% response \\
\hline Why Best Paddock? & \\
-animal performance (high) & 31 \\
-production (high) & 27 \\
-species & 22 \\
-age (young) & 20 \\
Why Worst Paddock? & \\
-species & 51 \\
-production (low) & 26 \\
-animal performance (low) & 12 \\
-age (old) & 11 \\
Why Persistent Paddock? & \\
-species & 39 \\
-age (old) & 24 \\
-grazing management & 21 \\
-fertility management & 16 \\
\hline
\end{tabular}

Table 2 Farmers' perceptions of the key reasons for pasture persistence in the selected survey paddock (highest 6 categories - 102 sample size).

\begin{tabular}{lc}
\hline Question asked & \% response \\
\hline Important factors and significant events & \\
influencing the persistence of this paddock & \\
-fertility/regular fertiliser & 29 \\
-grazing management & 28 \\
-species & 22 \\
-establishment & 9 \\
-moisture & 7 \\
-soil type/quality & 5 \\
\hline
\end{tabular}

Table 3 Average relative importance of individual farming factors to the whole farm operation (sample size 102).

\begin{tabular}{lc}
\hline Question asked & Rating $(0-20)$ \\
\hline How important is each of the following factors & \\
to your farming operation? & \\
Pasture quality & 18.27 \\
Animal health & 18.03 \\
Soil fertility & 17.23 \\
Pasture species persistence & 16.78 \\
Adequacy of subdivision & 15.74 \\
Shelter for stock & 15.44 \\
Seasonal feed gaps & 15.21 \\
Pest tolerance of pastures & 14.04 \\
Weed problems & 13.92 \\
Seasonal feed surpluses & 13.03 \\
Soil stability & 11.64 \\
LSD $5 \%$ & 1.22 \\
\hline
\end{tabular}

persist through into the 11-20 year bracket, according to the farmers perception of how long a perennial pasture should last. The actual pasture renewal rate of $5 \%$, equates to a 25 -year renewal rate. With just $32 \%$ of paddocks in the survey in the 21-year plus bracket and the expectation by $31 \%$ of farmers that a pasture 
should last more than 20 years, this comparison provides an interesting observation which could be interpreted in two ways. It may demonstrate that a significant percentage of farmers are not renewing their pastures when they believe them to be rundown, or that the persistence of pastures exceeds expectations.

\section{Management profile of the persistent paddock from the farmer's perspective - a summation}

The management characteristics of the persistent paddock (Table 5) are: grazing predominantly with sheep and sometimes cattle, as well it is used frequently for lambing and for finishing stock. It is more often part of a winter rotation than not, and it is slightly less often taken for hay or silage. The paddock is usually setstocked over lambing and during lactation up until weaning. Cattle are used infrequently, usually not during winter, and usually in association with sheep grazing as a feed control tool. The paddock is well maintained with fertiliser, often monitored with soil tests, considered to be on a rising plane of fertility and is overall better than average for the farm. The paddock is naturally free draining or has been developed to provide good drainage. Paddock size is similar or slightly larger than average for the farm. This paddock is usually grazed similarly to other paddocks on the farm. During discussions with

Table 4 Farmers' perception of how long a perennial pasture should last (years), the actual pasture renewal rate, and the age of the persistent survey paddock.

\begin{tabular}{cccc}
\hline Question asked & \% response & \% response \\
\hline How long should a perennial pasture last? (years) & & How old is the persistent survey paddock? (years) \\
$5-10$ & 23 & $5-10$ & 50 \\
$11-20$ & 45 & $11-20$ & 18 \\
$21+$ & 31 & $21+$ & 32
\end{tabular}

Actual pasture renewal rate on survey farms (sample size 102)

Average area sown to new pasture in the last 5 years (ha/yr) 20

Average area (cultivatable) per farm (ha) 439

Annual pasture renewal rate (\%)

Table 5 Farmers' perceptions about their persistent survey paddock (sample size 102).

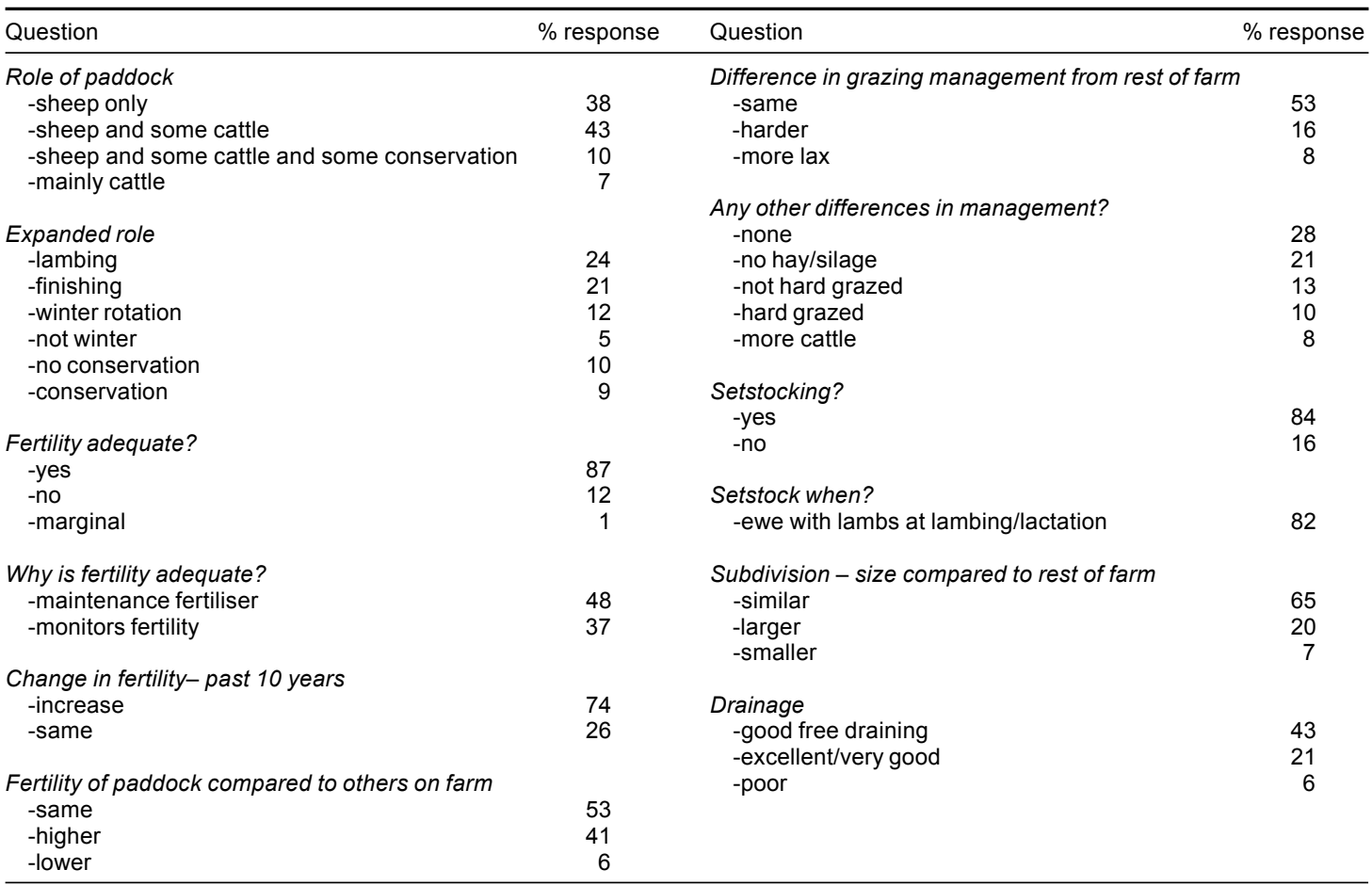

Note, for some questions not all the responses are listed. Those omitted were considered insignificant by the authors (<10\% response). 
the farmers, the interviewer also noted that in most cases the persistent paddock was never used as a sacrifice paddock (e.g., runoff or pad feeding paddock).

\section{How the farmer evaluations of their persistent paddock compared with actual species composition and soil fertility}

\section{Pasture species}

The paddocks have been grouped according to original sowings and labelled as; 'ryegrass only', 'ryegrass plus other grasses', (usually cocksfoot and or fescue) or 'Fescue or fescue + cocksfoot' (ryegrass not included at sowing). Specialist fescue or cocksfoot paddocks made up only small numbers of paddocks and so were grouped as 'Fescue or fescue + cocksfoot'. Chicory was only included in a small number of paddocks, usually as a minor component of a seed mix and therefore is insignificant in terms of presence. The group of paddocks in the 'ryegrass only' category were older than those in others, with just over $50 \% 21$ years and older. The other two categories had a younger mean age with a high proportion of paddocks in the 5-10 year age group (Table 6).

Table 6 Profiles for three pasture categories in the pasture persistence survey; number of paddocks, presence of species in turf cores, and fertility of paddocks.

\begin{tabular}{|c|c|c|c|}
\hline Paddocks sown to: & $\begin{array}{c}\text { Ryegrass } \\
\text { only }\end{array}$ & $\begin{array}{c}\text { Ryegrass } \\
+ \text { other } \\
\text { grass species }\end{array}$ & $\begin{array}{c}\text { Fescue or fescue } \\
+ \text { cocksfoot } \\
\text { (no ryegrass) }\end{array}$ \\
\hline \multirow[t]{2}{*}{ Number of Paddocks } & 38 & 20 & 15 \\
\hline & \multicolumn{3}{|c|}{--- Presence of species in cores\% } \\
\hline Ryegrass (Lolium perenne) & $73.8 \mathrm{a}$ & $60.2 \mathrm{~b}$ & $22.4 \mathrm{c}$ \\
\hline Cocksfoot (Dactylis glomerata) & $5.3 \mathrm{c}$ & $24.3 \mathrm{~b}$ & $39.2 \mathrm{a}$ \\
\hline Grazing Brome $^{1}$ (Bromus stamineus) & 0.6 & 2.0 & 3.6 \\
\hline Tall Fescue (Festuca arundinacea) & $1.0 \mathrm{~b}$ & $1.5 \mathrm{~b}$ & $22.9 a$ \\
\hline Phalaris $^{1}$ (Phalaris aquatica) & 0.6 & 0.2 & 1.9 \\
\hline Browntop (Agrostus tenuis) & $9.7 \mathrm{a}$ & $6.6 \mathrm{a}$ & $3.2 \mathrm{a}$ \\
\hline Other Perennial Grasses & $35.7 \mathrm{a}$ & $27.3 a b$ & $16.3 \mathrm{~b}$ \\
\hline Annual Grasses & $19.9 \mathrm{a}$ & $18.3 \mathrm{a}$ & $19.7 \mathrm{a}$ \\
\hline Chicory ${ }^{1}$ (Cichorium intybus) & 0.1 & 0.1 & 0.1 \\
\hline White Clover (Trifolium repens) & $40.8 \mathrm{a}$ & $33.1 \mathrm{ab}$ & $25.0 \mathrm{~b}$ \\
\hline Sub Clover (Trifolium subterraneum) & $3.8 \mathrm{a}$ & $5.2 \mathrm{a}$ & $7.1 \mathrm{a}$ \\
\hline Other annual clovers & $4.3 \mathrm{a}$ & $0.9 \mathrm{~b}$ & $4.5 \mathrm{a}$ \\
\hline Red Clover $^{1}$ (Trifolium pratense) & 0.7 & 1.5 & 1.7 \\
\hline Weeds (broadleafs) & $15.3 \mathrm{a}$ & $16.4 \mathrm{a}$ & $23.0 \mathrm{a}$ \\
\hline Bare ground & $2.3 \mathrm{a}$ & $3.0 \mathrm{a}$ & $3.5 \mathrm{a}$ \\
\hline \multicolumn{4}{|l|}{ Fertility } \\
\hline $\mathrm{pH}$ & $5.8 \mathrm{a}$ & $5.9 \mathrm{a}$ & $6.1 \mathrm{a}$ \\
\hline $\mathrm{K}$ & $8.8 \mathrm{a}$ & $9.7 \mathrm{a}$ & $10.3 a$ \\
\hline $\mathrm{P}$ & $21.3 \mathrm{a}$ & $22.0 \mathrm{a}$ & $24.5 \mathrm{a}$ \\
\hline S & $17.4 \mathrm{a}$ & $15.2 \mathrm{a}$ & $11.9 \mathrm{a}$ \\
\hline OS & $10.4 \mathrm{a}$ & $9.6 \mathrm{a}$ & $8.5 \mathrm{a}$ \\
\hline \multicolumn{2}{|l|}{ Age category of paddocks (years) } & \multicolumn{2}{|c|}{$\%$ of sample } \\
\hline $5-10$ & 23 & 70 & 86 \\
\hline $11-20$ & 23 & 10 & 14 \\
\hline $21+$ & 54 & 20 & 0 \\
\hline
\end{tabular}

Within a row, means followed by the same letter do not differ at $\mathrm{LSD}_{5 \%}$ (unrestricted) ${ }^{1}$ No means comparison because of the low incidence of presence for these species
Ryegrass presence in the turf cores (Table 6) was high at $74 \%$ in the 'ryegrass only' paddocks, indicating a good level of persistence. As expected, ryegrass presence was significantly less in the other two categories $(\mathrm{P}<0.05)$, and in the case of 'Fescue or fescue + cocksfoot' indicates a volunteer component, since ryegrass was not sown in these paddocks. Fescue is clearly highest in 'Fescue or fescue + cocksfoot' $(\mathrm{P}<0.05)$, and as a main sown species at $23 \%$ (Table 6 ) contrasts as much lower than ryegrass at $60 \%$ in the 'ryegrass plus other grasses'. When making this comparison it is important to look also at the significant presence of cocksfoot in the fescue paddocks. White clover was higher in 'ryegrass only' paddocks than 'Fescue or fescue + cocksfoot' $(\mathrm{P}<0.05)$.

The occurence of sown or desirable species in these paddocks compares very favourably with previous farm surveys. White clover presence in $41 \%$ of turf cores compares with Morton et al. (1993) who reported 32\% white clover presence in ryegrass pastures and Smith et al. (1998) who, for fescue and cocksfoot based pastures, reported a mean $32 \%$ and $52 \%$ white clover occurrence for North Island and South Island respectively. The survey of Smith et al. (1998) reported similar levels for annual grasses and other perennial grasses, but greater occurrence of browntop than recorded here. Weeds at $15-$ $20 \%$ presence are at similar levels to those found by Smith et al. (1993) in a survey of younger pastures on the East Coast of the North Island.

\section{Soil fertility}

Fertility levels of the survey paddocks (Table 6) are high compared to the average sheep and beef farm. A national database of soil test results (Wheeler \& Roberts 1997) over the period 1988-91, returned a mean value of Olsen P 13, pH 5.8 and S 6 for sheep/beef farms throughout the country, indicating that the fertility of the survey paddocks was significantly higher than average (particularly Olsen P and S). These are also high when compared with sheep and beef farm surveys of; 60 farms in North Otago, Olsen $\mathrm{P}$ 10, pH 5.7, S 5, (Fraser \& Hewson 1994), and on 91 farms in the East Coast of the North Island (Milne 
et al. 1993), with Olsen P levels of 15 . However, similar high fertility levels were found in a recent survey of fescue and cocksfoot paddocks (Smith et al. 1998), although ryegrass paddocks were not part of that study, and the pastures were all 6-7 years old.

\section{Discussion}

The authors' definition of persistence is 'when a pasture maintains over time, an acceptable balance of sown clover, grass and or herb content, and has a limited invasion of unsown grasses (e.g., browntop, ryegrass) and weeds (e.g., thistles)'. The persistent pastures, as identified by the farmers in this survey, each had high levels of desirable species. They also had low levels of weeds and of low-fertility volunteer species. This indicates that farmers qualitative assessment of their pastures did match our quantitative assessments. We cannot say for certain that the desirable species were the sown species but we could assume that this was likely in most cases. This aspect will be evaluated more rigorously in the long-term study with more detailed recording of seed species sown and composition changes from establishment.

A significant proportion of the pastures were over 21 years old, indicating that long-term persistence is possible with correct management. It is not possible to give an absolute management recipe, however a profile of the persistent paddocks has been described and some clear factors have been highlighted. Fertility was perceived to be an important aspect by the farmers and this point was substantiated by the quantitative soil test data. Two other factors that farmers identified to be important were drainage and the use of the paddock predominantly for sheep grazing.

Farmers' perceptions indicated that while persistence does rank as one of the more important factors to their whole-farm operation, it was clearly ranked behind pasture quality and animal performance. Animal performance is the product of pasture quality and quantity, and quality featured as a common descriptor used by farmers in determining which were their 'best' and 'worst' pastures.

Soil fertility and fertiliser input featured as a prominent management factor in the persistent pastures. Previous work has shown that withholding maintenance fertiliser results in a declining ryegrass and white clover (McBride et al. 1990) and increasing browntop (Ledgard $\&$ Bier 1993) content. The persistent pastures surveyed had a higher average Olsen P (21) than shown in previous farm surveys (Wheeler \& Roberts 1997). This phosphate level is considered to be at, or just above, the optimum level for production on sedimentary soils
(Morton et al. 1994). This would indicate that fertility has been a significant factor in the persistence of these paddocks.

\section{Conclusions}

Pastures can persist and maintain high levels of desirable species for periods over 21 years. Fertility was identified as the key management factor. A number of other factors that farmers believe to be associated with pasture persistence were identified. These factors will be included in pasture assessments made during the longterm study and can also serve as a guide to considerations for future research.

\section{ACKNOWLEDGEMENTS}

The authors thank Meat New Zealand and WoolPro for funding this project; the many farmers for their cooperation and input; Mark Paine and Terry Parminter for advice and direction on the social science aspects; Dave Saville for biometric support, and Brenda Stuart for species identification.

\section{REFERENCES}

AgResearch 1997. Soil testing - why and how. Agfact no 41.

Fraser, T.J.; Hewson, D.C. 1994. Establishing droughttolerant pasture species on east coast downlands by direct drilling. Proceedings of the New Zealand Grassland Association 55: 73-76.

Ledgard, S.F.; Bier, G.J. 1993. Response to reapplication of phosphate fertilisers on hill pastures where fertilisers have been withheld for seven years. Proceedings of the New Zealand Grassland Association 55: 67-71.

McBride, S.D.; Nguyen, M.L.; Richard, D.S. 1990. Implications of ceasing annual superphosphate topdressing applications on pasture production. Proceedings of the New Zealand Grassland Association 52: 177-180.

Milne, G.D.; Moloney, S.C.; Smith, D.R. 1993. Demonstration of dryland pasture species on 90 east coast farms. Proceedings of the New Zealand Grassland Association 55: 39-44.

Mitchell, K.J.; Glenday, A.C. 1958. The tiller population of pastures. New Zealand journal of agricultural research 3: 305-318.

Morton, J.; Roberts, A.H.C.; Edmeades, D.C. 1994. Fertiliser use on sheep and beef farms. Auckland, New Zealand, New Zealand Fertiliser Manufacturers Research Association. 38pp. 
Saville, D.J. 1990. Multiple comparison procedures: The practical solution. The American Statistician 44: 174-180.

Smith, D.R.; Slay, M.W.A.; Gray, M.H.; Milne, G.D. 1993. On-farm establishment of drought-tolerant pastures on the east coast of the North Island. Proceedings of the New Zealand Grassland Association 55: 33-39.

Wheeler, D.M.; Roberts, A.H.C. 1997. Soil Fertility Status of Sheep/Beef and Dairy farms in New Zealand 1988-91. New Zealand soil news 45: 9097. 
